\title{
Ammatillinen aikuiskoulutus aikuiskasvatuksen kentässä
}

\author{
Annikki Järvinen
}

\begin{abstract}
A ikuiskasvatuksen ja aikuisen oppimisen toimintaympäristöt ovat tänä päivänä hyvin monimuotoiset. Niitä ovat niin erilaiset instituutiot, organisaatiot, verkostot, virtuaaliympäristöt kuin sosiaaliset, yhteiskunnalliset ja uskonnolliset liikkeet sekä kansalaisjärjestöt. Oppiminen voi olla luonteeltaan niin kollektiivista, yhteistoiminnallista kuin yksilöllistä. Yhä selkeämmin aikuisen oppiminen organisoituu työhön ja arkeen, formaalin aikuiskoulutuksen ulkopuolelle.
\end{abstract}

Erilaiset sosiaaliset, alueelliset ja intellektuaaliset traditiot ovat tuottaneet nykyisen aikuiskasvatuksen ja -koulutuksen kompleksisen käytäntöjen kentän. Aikuiskasvatuksen lähihistorian kehitys kietoutuu 1800-luvulla voimistuneisiin yhteiskunnallisiin muutosprosesseihin, kuten teollistumiseen, maallistumiseen, työväenliikkeen nousuun, kaupunkien voimakkaaseen kasvuun ja kansallisvaltion rakentamiseen. Monissa eurooppalaisissa, toisilleen vastakkaisissakin liikkeissä oli vahva emansipatorinen orientaatio ja yhteisenä perustana valistuksen projekti. Poliittiset ja kansalaisliikkeet vahvistivat jäsentensä identiteettiä: yhteisen historian tuntemusta ja yhteisen tulevaisuuden etsintää. Eurooppalaisen aikuiskasvatuksen juuret ovat tässä liikehdinnässä, vaikkakaan sotien jälkeisessä hyvinvointivaltion konseptissa ei aikuiskasvatuksella ja -koulutuksella ollut vielä merkittävää funktiota. Aikuiskasvatukselle kehittyi useissa Euroopan maissa kaksi eri väylää; toisaalta yleissivistävän aikuiskasvatuksen väylä eli Suomessa nk. vapaa sivistystyön sektori, ja toisaalta ammatillisen koulutuksen väylä. Vähitellen työorientointuneen aikuiskoulutuksen markkinat laajenivat kaikissa maissa. Isot organisaatiot ja yritykset järjestävät omaa henkilöstökoulutustaan ja samanaikaisesti on lisääntynyt lukuisten koulutusta tarjoavien yritysten lukumäärä. Työelämän ja yhteiskunnan edelleen jatkuva nopea muutosvauhti on muuttanut aikuiskasvatuksen roolia, se ei ole enää vain yksi yhteiskunnan toimintakenttä vaan sosiaalisen muutoksen tekijä.

$\mathrm{V}$ iime keväänä ilmestyi eurooppalaisten aikuiskasvatuksen tutkijoiden vahva puheenvuoroteos, jonka kirjoittajat tarkastelevat aikuiskasvatuksen asemaa nykyisessä postmodernissa ajassa. He nostavat esiin mm. aikuiskasvatuksen identiteetin ja mission, painopisteen siirtymisen kasvatuksesta oppimiseen sekä yksilöllisyyden ja sosiaalisen vastuun (Finger et al. 1998). Kun seuraavassa tarkastelen näitä kysymyksiä, pohdin myös, löytyykö aikuiskasvatuksen parhaasta emansipatorisesta ja pragmaattisesta perinteestä maamerkkejä myös ammatillisen aikuiskoulutuksen tutkimukselle ja kehittämiselle?

Epäily ja skeptisismi ovat vallanneet alaa niiden aikuiskasvattajien mielissä, jotka katsovat, että postmodernissa ajassa aikuiskasvatuksen "valistuksen missio" ja emansipatorinen intressi, ts. pyrkimys tasa-arvoisempaan yhteiskuntaan, on saanut väistyä hyvinvointivaltion ohjauskyvyn vähenemisen myötä. Samalla markkinahenkinen aikuiskoulutus valtaa lisää alaa. Moraali privatisoituu, valtio ei enää toimi moraalisten debattien ja taistelujen areenana. Valtion tehtävä on ennen kaikkea luoda mahdollisuuksia kansalaisten itsensä toteuttamiselle ja ylläpitää lakia ja järjestystä. Politiikan sisältöjä vaaditaan arvioitavaksi uudelleen. Yhtäältä uusia teemoja ovat kansallisvaltion ylä- 
puolelle asettuvat teemat, kuten globaalit ihmisoikeudet ja ekologiset oikeudet ja toisaalta sen alapuolella olevalla tasolla alueellinen, paikallinen ja henkilökohtainen politiikka. Välttämätön edellytys kansalaisen olemassaololle ja demokraattiselle osallistumiselle on pääsy sekä globaaleihin että paikallisiin kommunikaatio- ja informaatioverkkoihin. On sanottu, että sekä julkisessa että yksityisessä elämässä ei ole enää kiinnostavaa "olla jotakin" vaan "tulla joksikin"; olemassaolo on jatkuvan tarkastelun, uusien kokemusten etsimisen ja kommunikaation kohde. Siksi refleksiivinen moderni yhteiskunta, kuten yhteiskuntatutkijat tätä kutsuvat, on olennaisella tavalla oppiva yhteiskunta, missä elinikäinen oppiminen on sen tunnusmerkki. (Finger et al. 1998)

\section{E} linikäinen oppiminen siirtyy yhä enenevässä näärin instituutioiden ulkopuolelle. Tämän kehityksen katsotaan johtavan aikuiskasvatuksen välineellistymiseen ja privatisoitumiseen (emt). Välineellistymisen yksi piirre on, että taitava ja osaava työvoima on yritykselle yhä tärkeämpi kilpailutekijä. Aikuiskoulutuksen terminologiakin heijastaa yhä lisääntyvää markkinahenkisyyttä: se on "asiakaskeskeistä, työmarkkinaorientoitunutta, räätälöityjä tuotteitta tarjoavaa” jne. Privatisoituminen näkyy enenevässä määrin siinä, että oppijan on otettava henkilökohtainen vastuu oppimisestaan. Toisaalta aikuiset oppijat arvioivat oppimansa merkitystä oman elämäntapansa ja omien elämänvaiheidensa kannalta, ja tuo tarkastelu määrittää myös oppimisen tavoitteita.

Monet aikuiskasvattajat ovat hämmennyksen vallassa, koska aikuiskasvatuksen institutionaalinen merkitys ja siihen liittyvä vallankäyttö, joka on kietoutunut modernin projektin suuriin kertomuksiin, vähenee. Tilalle on tullut kirjava toimijoiden kenttä ja epävarmuus. Benn ja Fieldhouse (1994) esittävät kuitenkin kriittisen näkemyksen, jonka mukaan aikuiskasvatuksen sitoutumista emansipaatioon ja sosiaaliseen yhdenvertaisuuteen on laimentanut voimakas sitoutuminen yhdenmukaisiin standardeihin, ja ns. "objektiiviseen" tietoon, sekä vahva patriarkaalisuus. Kyse on siitä, miten kansaa valistetaan, kuka valistaa ja millä valtuutuksella? Työväenliikkeenkin radikaalin diskurssin on katsottu huolehtineen lähinnä valkoi- sen järjestäytyneen miespuolisen työläisen eduista. Kritiikki erityisesti aikuiskasvatuksen patriarkaalista luonnetta vastaan on noussut $\mathrm{mm}$. feministitutkijoiden, vaihtoehtoliikkeiden ja kolmannen maailman edustajien taholta (Edwards \& Usher, 1998). On todettava, että aikuiskasvatuksen johtavissa hallinto- ja tutkimustehtävissä vallitsee vielä nykyäänkin lähes tulkoon mieshegemonia, vaikka opiskelijajoukko aikuiskoulutuksessa ja erityisesti vapaan sivistystyön sektorilla on vahvasti naisvaltainen.

$\mathrm{M}$ iten sitten kuvata aikuiskasvattajan muuttuvaa roolia? Zygmund Bauman (Edward \& Usher 1998 mukaan, 51) on kuvaillut sitä mielestäni varsin sattuvin kielikuvin. Hän toteaa mm., että aikuiskasvattajan tulisi olla kommentaattori mieluummin kuin lainsäätäjä, tulkitsija pikemminkin kuin valaistunut pedagogi, kulttuurityöntekijä mieluummin kuin valistuksen lähetyssaarnaaja ja aitojen kaataja mieluummin kuin paimen.

Kompleksisuus, pirstoutuminen ja ambivalenssi, jotka luonnehtivat postmodernia aikaa, heijastuvat myös henkilökohtaiselle tasolle. Tällöin aikuiskasvatuksessa keskeistä aikuisen identiteetin käsitettä joudutaan tarkastelemaan uudella tavalla. Identiteetin etsintä ja rakentaminen sinänsä ei ole kadonnut, mutta sen rakentaminen yhä uudelleen on globalisaation ja muuttoliikkeiden takia monimuotoisempaa. Puheenvuoroteoksen kirjoittajien eräs loppupäätelmä on, että aikuiskasvatuksen tärkeä tehtävä tässä ajassa on vahvistaa aikuisen sosiaalista ja kulttuurista identiteettiä, modernia kansalaisuutta (Jansen et al 1998). Tämä merkitsee täysivaltaista yhteiskunnan jäsenyyttä oikeuksineen ja velvollisuuksineen. Aikuiskasvatuksen tulee tarjota mahdollisuuksia hankkia niitä laaja-alaisia kvalifikaatioita, joita tarvitaan sosiaaliseen, kulttuuriseen ja poliittiseen osallistumiseen. Oppimisympäristöjen tulee stimuloida ihmisiä tarkastelemaan kriittisesti kokemuksiaan kansalaisina ja työntekijöinä. Kirjoittajien mukaan aikuiskasvatuksen tutkimuksen tulisi selvittää, miten tukea aikuisen elämäkerrallista ja sosiaalista oppimistayksilöllisessä ja kollektiivisessa ongelmanratkaisussa sekä sosiaalisen vastuun ottamisessa (emt). 
$\mathrm{J}$ os kulttuurisen ja sosiaalisen identiteetin tukeminen on yhä tärkeämpää, voidaanko puhua enää työidentiteetistä? Tanskalainen aikuiskasvatuksen tutkija, professori Henning Salling Olesen (1998) katsoo, että työidentiteetin tutkimus on kiinnittynyt liiaksi teollisuussosiologian ja yhteiskuntatieteellisen taloustieteen käsitteistöön ja lähestymistapoihin. Työn subjektiivista merkitystä ei voida lähestyä myöskään puhtaasti psykologisin termein. Salling Olesen on tutkijaryhmänsä kanssa kehittänyt uuden kvalifikaatioiden tutkimusmallin. Siinä identiteetin käsite sisältää ne perustavat persoonalliset sekä sosiaalisen elämän ja työelämän kvalifikaatiot, jotka ihminen tarvitsee voidakseen toimia yksilönä ja kansalaisena yhteiskunnassa. Identiteetti merkitsee siis kykyä integroida nämä jännitteiset osa-alueet. (Andersen et al. 1994)

Sen sijaan, että tarkastelemme työprosesseja ja yhteiskunnallisia trendejä aikuisen oppimisen ja aikuiskasvatuksen ulkoisina ehtoina, meidän tulee Olesenin mukaan tutkia työtä ja työmarkkinoita kokemusten ja oppimismahdollisuuksien kenttinä (Salling Olesen, 1998). Tässä tarkastelussa eräs keskeinen tekijä on työn merkityksen luonteen muuttuminen. Useissa eurooppalaisissa tutkimuksissa on todettu, että nuoret ihmiset arvioivat työtä siltä kannalta, tarjoaako se heille mahdollisuuksia itsensä kehittämiseen ja toteuttamiseen. Työ on vain yksi niistä areenoista, joilla voi ilmaista elämäntyyliään (emt) Kuva poikkeaa radikaalisti siitä työsidonnaisesta elämäntavasta, joka on hallinnut keski-ikäisen ja vanhemman väestönosan elämää.

$\mathrm{O}$ nko ammatillinen identiteetti puolestaan johdettavissa muusta lähteestä kuin samaistumisesta työtehtäviin tai ammatilliseen rooliin? Tutkijat Meijers ja Wijers (1998) tarjoavat uuden mielenkiintoisen näkemyksen uraidentiteetin muodostumisesta. He toteavat, että sen sijaan, että kysymme, mitä työ merkitsee minulle, tulisikin kysyä, minkälaisia merkityksiä haluan työni välityksellä viestiä muille ihmisille. Uraidentiteettiä tulee rakentaa yksilön omista autenttisista arvoista käsin, joita analysoidaan esiin oman elämän teemoista ja kokemuksista, työstetään luovan oppimisprosessin avulla ja suhteutetaan työhön (emt
80-88). Heidän mukaansa tämän prosessin edellytyksiä ovat vahva oppimisympäristö ja oppimista tukeva yhteisö.

\begin{abstract}
$\mathrm{A}$ ikuiskasvatuksen yksilöllistymisen lisääntyessä painopiste on siirtynyt kasvatuskäsitteestä oppimiskäsitteeseen. Samanaikaisesti on tapahtunut siirtymistä normatiivisesta pragmaattiseen lähestymistapaan ja kollektiivisesta yksilölliseen painotukseen. Merkitseekö se myös sitä, että aikuinen jätetään oman onnensa nojaan oppijana? Miten tukea aikuisen yksilöllisiä oppimisprosesseja?
\end{abstract}

Tähän hakee vastausta em. puheenvuoroteoksessa $\mathrm{mm}$. belgialainen aikuiskasvatuksen tutkija Danny Wildemeersch (1998). Hän tutki hollantilaisten maanviljelijöiden suhtautumista kestävään kehitykseen, ja totesi, että todellista muutosta, josta hän käyttää termiä elämismaailman muuntuminen, tapahtui vasta eri yhteiskunnallisten toimijoiden julkisen debatin tuloksena. Kyse oli eri näkemysten edustajien argumenttien vaihtamisesta ja jatkuvasta dialogista. Metodina oli elämäkertatyöskentelyn yhdistäminen verkostokommunikaatioon. Wildemeersch näkee aikuiskasvattajien uutena tehtävänä ylläpitää keskeisissä kysymyksissä julkista debattia, ja tukea sitä oppimisprosessina. Siinä tulee saada eri toimijoiden näkemykset ja argumentit esille ja auttaa aikuisia reflektoimaan aikaisempia kokemuksiaan ja omaa elämäkertaansa suhteessa käsiteltävään asiaan.Samantyyppinen toimintarooli on löydettävissä myös työorganisaatioissa. Henkilöstökouluttajan konsultatiivinen ja ryhmäprosesseja tukeva työote auttaa tuotantoprosessissa eri toimijoiden ja tiimien näkemysten vaihtoa ja synnyttää uusia ratkaisuja. Kysymys on organisaatiossa tapahtuvan tiedon tuottamisprosessin tukemisesta (Järvinen, 1997).

$\mathrm{M}$ itä nuo edellämainitut, aikuiskasvatuksen muuttunutta roolia kuvaavat näkemykset sitten merkitsevät ammatillisen aikuiskoulutuksen sektorilla? Seuraavassa esitän eräitä pohdintoja ja sovelluksia.

Nyky-yhteiskunnassa aikuisen elinikäisen oppimisen kaareen sisältyy sekä yleissivistäviä että 
ammatillisia koulutusjaksoja, jotka limittyvät hänen henkilöhistoriastaan ja elämäntilanteestaan riippuen hyvin eri tavoin. Ammatillista ja yleissivistävää opiskelua ei tule nähdä vastakkaisina vaan toisiaan täydentävinä. Monet työelämän uudet pätevyydet ovat itse asiassa luonteeltaan yleissivistäviä. Sellaisia ovat esimerkiksi resurssien hallinta, yhteistyötaidot, tiedon hankinta ja käyttötaidot, vuorovaikutussuhteiden hallinta ja teknologian hyödyntäminen. Erityispätevyyksiin tähtäävää koulutusta on mielekästä rakentaa vasta näiden laaja-alaisten yleispätevyyksien hallinnan varaan. Ne takaavat sen, että aikuinen voi työhistoriansa aikana paremmin omaksua uusia työtehtäviä tai siirtyä uuteen ammattiin, minkä hän elinaikanaan joutuu hyvin todennäköisesti tekemään.

Y leissivistävässä aikuiskoulutuksessa on puolestaan yhä enemmän elementtejä, joita voidaan pitää ammatillisina tai asiantuntijakoulutukseen kuuluvina. Tällaisia ovat mm. monet ekologiaan ja kestävään kehitykseen liittyvät yleissivistävät koulutusjaksot. "Pätevän kansalaisen" ideaan kuuluu se, että kansalaisyhteiskunnan aktiivina jäsenenä aikuinen pystyy itsenäisesti ja kriittisesti ottamaan kantaa laajoihin koko yhteiskuntaa ja hänen henkilökohtaista elämäänsä koskettaviin kysymyksiin. Hän pystyy myös kritikoimaan asiantuntijoiden ja poliitikkojen suunnitelmia ja päätöksiä ja vaatimaan muutoksia. Monimutkaistuvassa yhteiskunnassa tulee yleissivistävän aikuiskoulutuksen tarjota mahdollisuuksia kehittää valmiuksia tuohon toimintaan. Tähän viittaa myös valtioneuvoston 21.12.95 (VN 1995) päivätyssä kehittämissuunnitelmassa maininta siitä, että yleissivistävää aikuiskoulutusta kehitetään siten, että se parantaa aikuisten toimintaedellytyksiä kansalaistoiminnassa. Useimpien suomalaisten aikuisten elämänkaari sisältää työelämän ulkopuolelle jääviä jaksoja. Siksi heidän identiteettinsä tukeminen kehittämällä työkvalifikaatioiden lisäksi sosiaalisia ja persoonallisia kvalifikaatioita, on haaste myös ammatilliselle aikuiskoulutukselle.

Em. kehittämissuunnitelma ottaa kantaa ammatilliseen aikuiskoulutukseen toteamalla, että siinä annetaan sekä työelämän spesifejä taitoja että laaja-alaista ammatillista peruskoulutusta. Lisäksi to- detaan, että erityisosaamiseen liittyvä ammatillinen aikuiskoulutus korkeakoulujen ulkopuolella järjestetään pääosin ammattitutkintoihin ja erikoisammattitutkintoihin johtavana koulutuksena. Ammattitutkintojen katsotaan tarjoavan ammatillisen pätevyyden osoittamisen mahdollisuuden $\mathrm{mm}$. sille aikuisväestölle, jolta puuttuu perusasteen jälkeinen tutkinto (noin neljä prosenttia 2565-vuotiaista). Ammattitutkintojen suoritusmäärien odotetaan lähivuosina voimakkaasti nousevan. Tämä uusi tutkintomuoto, kuten myös aikuisten ammatillisen peruskoulutuksen kehittäminen, vaatii mm. kvalifikaatiotutkimukselta aivan uudentyyppistä tutkimusorientaatiota. Käsite "ammatillinen aikuiskoulutus" sisältää perusjännitteen: ammatillisuus työelämän tarpeista nousevana vs.s aikuisen henkilökohtaisten kehitystarpeiden määrittämänä. Työelämälähtöisen aikuiskoulutuksen suunnittelu nähdään usein liian lyhytjänteisenä ja markkinoiden muutoksille alttiina. Korkean työttömyyden vallitessa siitä muodostuu herkästi työvoimapoliittinen keino; toisaalta esiintyy tiukan spesifejä ja ylimitoitettujakin vaatimuksia työvoiman laadulle, toisaalta aikuiskoulutusta käytetään työvoiman varastoimisen välineenä. On myöskritikoitu työelämälähtöistä ja työpaikkasidonnaista aikuiskoulutusta siitä, että se sysää syrjään tietyt työelämän marginaaliset ryhmät, kuten työelämään pyrkivät nuoret. - Työelämässä tapahtuva opiskelu voi sisältää henkilökohtaisia pätevöitymis- ja kehitystavoitteita. Se voi sisältää myös koko organisaation yhteisistä muutospyrkimyksistä nousevia tavoitteita, kuten uusien toimintatapojen omaksumista ja uudenlaisen pätevyyden tuottamista. Tällöin joudutaan tutkimaan mahdollisuuksia, miten henkilökohtaiset kehitysohjelmat ja työorganisaation kehittämisohjelmat voidaan niveltää toisiinsa.

Aikuisopiskelija voi tehdä henkilökohtaisen ammatillisen koulutussuunnitelman, joka nojaa hänen aikaisempaan opiskelu- ja työhistoriaansa. Kysymys on tällöin oman ammatillisen identiteetin määrittämisestä ja muovaamisesta. Ammatillisen aikuiskoulutuksen eräs tehtävä on taata aikuisopiskelijalle mahdollisuus hankkia uusia laaja-alaisia pätevyyksiä. Toisaalta hänen tulee voida hankkia myös spesifejä erityispätevyyksiä. Ammatilliseen koulutukseen osallistuvat aikuisopis- 


\section{I R K A A N A S T U J A I S E S I T E L M ̈̈}

kelijat muodostavat hyvin moniaineksisen joukon, kun tarkastelemme sitä vaikkapa vain iän, aikaisemman koulutuksen, sukupuolen ja työelämäkokemuksen valossa. Tästä syystä aikuiskoulutus on hyvin vaativien suunnittelu- ja kehittämistehtävien edessä. Seurauksena ovat paineet mm. aikuisopintoneuvojien ja aikuiskouluttajien koulutukseen.

\section{Y} ksi keskeinen kysymys ammatillisen aikuiskoulutuksen kehittämisessä ovat koulutusratkaisuja ohjaavat oppimisnäkemykset. Merkittäviä ovat ne oppimisnäkemykset, jotka korostavat aikuisen oman kokemusmaailman huomioon ottamista ja sen kriittistä reflektointia, oppimisen kontekstuaalisuutta sekä oppijan uuden perspektiivin hahmottamista ja uudentoimintasuunnitelman luomista. Tämän alueen tutkimustoimintaa on Suomessa jo hieman virinnyt, mutta aikuiskoulutuksen monimuotoisessa kentässä sitä tarvitaan huomattavasti laajemmalla rintamalla.

$\mathrm{E}$ räs haastavimpia ammatillisen aikuiskouluuksen tutkimuksen alueita on formaalin sekä non- ja informaalin oppimis- ja koulutusympäristön integroiminen aikuisen elämänkaaren eri vaiheissa mielekkäällä tavalla. Tämän “mielekkyyden“ teoreettisena jäsentäjänä toimii mezirowilainen näkemys aikuisen pyrkimyksestä integriteettiin eli eheyteen elämänsä eri osa-alueiden kanssa. Ammatillisessa aikuiskoulutuksessa se merkitsee oman ammatillisen identiteetin (osaamisen) etsimistä, tunnistamista ja sen liittämistä muihin elämänalueisiin. Suuren uhkan identiteettiävahvistavalle ammatilliselle aikuiskoulutukselle muodostaa ns. epätyypillisten työsuhteiden ja rutiininomaisen toistotyön lisääntyminen työmarkkinoilla. "McDonalds'aatioksi" nimitetty ilmiö näyttää lisääntyvän, vaikka tietoyhteiskunnasta puhuttaessa onkin annettu se kuva, että rutiinityöt korvautuvat vähitellen high tech- tai siihen liittyvällä korkeaa koulutusta vaativalla osaamisella, kuten Tero Autio toteaa viimeisimmän Aikuiskasvatus-lehden artikkelissa (Autio, 1998, 192).

\footnotetext{
$\mathrm{A}$ mmatillisen aikuiskoulutuksen toimijoiden kenttä ja toteutustavat ovat hyvin monimuotoisia. Erään määritystavan mukaan ammatilliseen aikuiskoulutukseen Suomessa luetaan kuuluvaksi
}

henkilöstökoulutus, oppisopimuskoulutus, työvoimapoliittinen aikuiskoulutus, ja omaehtoinen ammatillinen aikuiskoulutus (TM 1997). Laajemman määrityksen mukaan siihen on luettavissa myös ammatillinen jatko- ja täydennyskoulutus korkeakouluissa ja oppilaitoksissa. Tilastokeskuksen viime vuonna julkaiseman aikuiskoulutustutkimuksen mukaan (Blomqvist et. al. 1997) vuonna 1995 noin miljoona aikuistaosallistui ammattiin tai työhön liittyvään koulutukseen. Naisetosallistuivat aktiivisemmin kuin miehet. Omaehtoiseen ammatilliseenaikuiskoulutukseen eli omalla kustannuksella osallistui noin 100.000 suomalaista, ja heistä oli peräti 71 prosenttia naisia. Eniten työhön tai ammattiin liittyvään koulutukseen osallistuivat ylemmät toimihenkilöt (71 prosenttia), kun taas työntekijöistä osallistui 35 prosenttia. Viimeksi mainittu luku on kuitenkin kasvanut verrattuna vuoteen 1990, joten henkilöstökoulutuksen polarisaatio on hieman lieventynyt. Sen sijaan yrittäjien, lukuun ottamatta maatalousyrittäjiä, koulutukseen osallistuminen on vähentynyt ollen vuonna 1995 vain 24 prosenttia (emt).

Viimeksi mainittu luku tuo esiin sen tosiseikan, että henkilöstökoulutuksen sektorilla erityisesti pienten ja keskisuurten yritysten koulutusmahdollisuudet ovat heikot. Isoilla organisaatioilla on usein varsin monipuolista henkilöstökoulutuksen tarjontaa, ja ne käyttävät yhäenenevässä määrin myös tutkimuspohjaista tietoa henkilöstön ja organisaation kehitystyössä. Tästä ovat hyvänä esimerkkinä Kansallisen Työelämän Kehittämisohjelman sadat innovatiiviset kehittämishankkeet (TM 1998). Aikuiskasvatuksen ja työssä oppimisen tutkimuksella on tarjotamonimuotoisia uusia oppimisen organisoimisen ratkaisuja työpaikoille. Tästäesimerkkinä kehittävän työntutkimuksen lähestymistapa oppimislaboratorioineen (Virkkunen et al. 1997), osallistavan uudelleensuunnittelun metodi, itseohjautuvat oppimisprojektit ja oppivan organisaation monet sovellukset. Näitä lähestymistapoja pystyvät isot yritykset hyödyntämään, mutta PK-sektorilla ne ovat usein liian kalliita ja aikaa vieviä ratkaisuja. Siellä kaivataan henkilöstökoulutuksen ja työssä oppimisen kehittämiseenuusia yhteistyöfoorumeita ja rahoitusmalleja. Vuoden vaihteessa laitoksessamme päättyvä LEONARDO-tutkimushanke, analysoi PK-sektorin 
henkilöstökoulutuksen tilaa ja erilaisia ratkaisumalleja viidessä eri Euroopan maassa. Erääksi ratkaisuksi Suomessa tullaan esittämään alueellinen ja osittain toimialakohtainen PK-sektorin koulutusmalli eli kehitysorganisaatio. Se perustuu eri toimijaosapuolien, kuten TE-keskusten, alueen yrittäjien, aikuisoppilaitosten ja koulutustoimikuntien tiiviiseen yhteistyöhön (Orelma \& Järvinen, 1999). Malli on esimerkki siitä uudenlaisesta verkostoitumisesta, mitä ammatillisen aikuiskoulutuksen sektorilla jo tapahtuu, ja jota tarvitaan lisää.

Tampereen yliopiston kasvatustieteiden tiedekunta onkin omalta osaltaan ennakkoluulottomasti lähtenyt luomaan uutta yhteistyöfoorumia perustamalla tiedekuntaan Koulutuksen Kehittämisyksikön. Sen tarjoamiin työelämää jaammatillista aikuiskoulutusta niveltäviin ohjelmiin on viime vuoden keväästä asti osallistunut jo yli $700 \mathrm{am}$ matillisen aikuiskoulutuksen asiantuntijaa. Lähivuosina tulee yksikön toiminnassa painottumaan tutkintotavoitteisuus, ohjelmien pitkäkestoisuus, kehitysprosessien seuraaminen ja työssä oppimisen uusien muotojen kehittäminen ja tutkimus.

\begin{abstract}
$\mathrm{A}$ mmatillisen aikuiskoulutuksen tulee aikuiskasvatustieteen lähtökohdista käsin perustaa tutkimuksensa aikuisen identiteetin ja eheyttämispyrkimystentukemiseen ja vahvojen oppimisympäristöjen kehittämiseen työpaikoilla. Tämän aikuiskoulutuksen osa-alueen omana tärkeänä tehtävänä on tukea aktiivisesti eri toimijaosapuolten jatkuvaa dialogia alan kehittämistyössä.
\end{abstract}

\section{VIITTEET}

Andersen, V. et al. ( 1994) Qualifications and living people. Adult Education Research Group. University of Roskilde.

Autio, T. (1998) Sosiokulttuurisen kontekstin muutos, koulutuspolitiikka ja laatu. Aikuiskasvatus 188-199.

Benn, R. \& Fieldhouse, R. (1994) Raybouldism, Russell and New Reality. Teoksessa: Armstrong, B. et al. (eds.): Reflecting on Changing Practices, Contexts and Identities. Hull: SCUTREA

Blomqvist, I. et al. (1997) Aikuisopiskelu Suomessa. Tilastokeskus. Koulutus 1997/4

Edwards, R. \& Usher,R. (1998) Modern field and postmodern moorland: adult education bound for glory or bound and gagged. Teoksessa Wilde-
meersch,D. \& Finger,M. \& Jansen,T. (eds.) Adult Education and Social Responsibility. Frankfurt am Main: Peter Lang. Ss. 27-56

Finger,M. \& Jansen,T. \& Wildemeersch,D. (1998) Recociling the irreconcicable? Adult and continuing education between personal development, corporate concerns and public responsibility. Teoksessa Wildemeersch,D. \& Finger,M. \& Jansen,T. (eds.) Adult Education and Social Responsibility. Frankfurt am Main: Peter Lang. Ss. 1-26.

JANSEN, T. \& Finger,M. \& Wildemeersch,D. (1998) Reframing reflectivity in view of adult education for social responsibility. Teoksessa Wildemeersch,D. \& Finger,M. \& Jansen,T. (eds.) Adult Education and Social Responsibility. Frankfurt am Main: Peter Lang. Ss. 237-248.

JÄRVINEN, A. (1997) Oppimisen organisoiminen työyhteisössä. Teoksessa: Raivola,R., Valtonen, P. \& Vuorensyrjä, M. (toim.): Koulutus, yhteiskunta, menestys. Suomen Akatemian koulutuksen vaikuttavuusohjelman tutkimuksia. Helsinki:Educa. ss. 118132

KOIVISTO, T. (1997) Uudistuva metallialan tuotantolaitos. Väitöskirja. Acta Universitatis Tamperensis 558.

MEIJERS, F. \& Wijers,G. (1998) Flexibilisation or career identity? Teoksessa Wildemeersch,D. \& Finger,M. \& Jansen,T. (eds.) Adult Education and Social Responsibility. Frankfurt am Main: Peter Lang. Ss. 7396.

MEZIROW, J. (1991) Tranformative dinmensions of adult learning. San Fransisco: Jossey-Bass Incl.

ORELMA, A. \& Järvinen, A. (1999) PK-sektorin henkilöstökoulutuksen kehittely - sektoraalinen näkökulma. Tampereen yliopiston kasvatustieteiden laitos. LEONARDO-hankeraportti. Tulossa.

POELL, R. (1998) Organizing Work-related Learning Projects. A Network Approach. Nijmegen, Katholieke Universiteit.

SALLING OLESEN, H. (1998) Break up in traditional work identities - theorizing the subjective side of work. Teoksessa Salling Olesen,H. (ed.) Adult Education and The Labour Market IV. Ss. 193-210.

TM (1997) Henkilöstökoulutuksen kehittäminen. Neuvottelumuistio. Työministeriö.

TM (1998) Kansallisen työelämän kehittämisohjelman eteneminen. Johtoryhmän väliraportti talousneuvostolle. Työministeriö.

VANDENABEELE,J. \& Wildemeersch,D. (1998) Learning for sustainable development: examining lifeworld transformation among farmers. Teoksessa Wildemeersch,D. \& Finger,M. \& Jansen,T. (eds.) Adult Education and Social Responsibility. Frankfurt am Main: Peter Lang. Ss. 115-132.

VIRKKUNEN, J. et al. (1997) Muutoslaboratorio - väline työn uudistamiseen. Teoksessa Alasoini, T. \& Kyllönen, M. \&Kasvio, A. (toim.) Työelämän innovaatiot. Kansallinen työelämän kehittämisohjelma. Vuosikirja 1997. Työministeriö, raporttteja 2. Ss. 155-172.

VN (1995) Koulutuksen ja korkeakouluissa annettavan tutkimuksen kehittämissuunnitelma vv. 1995-2000. Valtioneuvosto kehittämissuunnitelma 21.12.1995. 